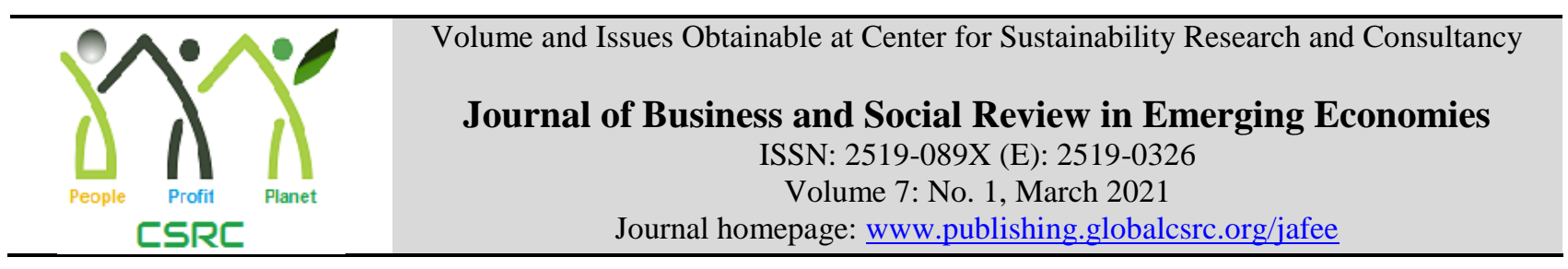

\title{
Coronavirus and Cognitive Dissonance, Behavior of Pakistanis during Pandemic Peak: A Study of Educated and Uneducated Citizens of Lahore
}

Atif Ashraf, Faculty of Media and Communication Studies, University of Central Punjab, Lahore, Pakistan

*Ghulam Shabir, Faculty of Media and Communication Studies (FMCS), University of Central Punjab, Lahore, Pakistan

Hafiz Abdur Rashid, Hailey College of Commerce, University of the Punjab, Lahore, Pakistan Qamar Uddin Zia Ghaznavi, Beacon House National University, Lahore, Pakistan

*Corresponding author's email address: ghulam.shabir@ucp.edu.pk

\begin{tabular}{ll}
\hline \multicolumn{1}{c}{ ARTICLE DETAILS } & ABSTRACT \\
\hline History & Purpose: This research aims to investigate the behavior of the \\
Revised format: Feb 2021 & $\begin{array}{l}\text { citizenry residing in Provincial Capital of Pakistan's largest } \\
\text { Available Online: } \text { Mar 2021 }\end{array}$ \\
populated province of Punjab.
\end{tabular}

Keywords

Coronavirus, Cognitive

Dissonance, Public Behavior,

Quantitative Approach.

JEL Classification:

M11, M12

OPEN $\bigcirc$ ACCESS
Methodology: Based on quantitative approach, a questionnaire with closed ended questions was distributed between two divisions of society - educated and uneducated - to measure their behavior towards the pandemic. The researchers have made an attempt to measure the cognitive dissonance of the society towards COVID with this hypothetical assumption that uneducated people would bother least as compared to the educated class.

Findings: The research concluded the educated class had adopted more precautionary measures as compared to the uneducated class. However, there was a slight negation in awareness level of the educated and uneducated class regarding the pandemic. More precisely, the findings also surfaced cognitive dissonance theory in relation to the education, implying that regardless of the COVID-19 awareness and the spread, uneducated people are more likely in the state of cognitive dissonance that the educated people.

Implications: Pakistani government as well as masses need to follow the response strategies of the government and awareness methods adopted by the people of China.

(C) 2021 The authors, under a Creative Commons AttributionNonCommercial 4.0

Recommended citation: Ashraf, A., Rashid, H. A., Shabir, G. \& Ghaznavi, Q. U. Z. (2021). Coronavirus and Cognitive Dissonance, Behavior of Pakistanis during Pandemic Peak: A Study of Educated and Uneducated Citizens of Lahore. Journal of Business and Social Review in Emerging Economies, 7(1), 149-158.

\section{Introduction}

Taking a step head in decades in human history, the coronavirus has infected human beings (Covid et al., 2020; Perlman, 2020) and has led to severe consequences of losses of life and property. Coronavirus 
is becoming a dangerous that to human life with each passing day across the globe (Seah, Su, \& Lingam, 2020). Coronavirus, sometimes believed as hoax, is not that exactly as once reiterated by an American President Donald Trump (Rose, 2020). Coronavirus has changed the entire political, economic and social landscape across the globe. Before coronavirus was surfaced in China, social life had different fabric as compared to the social structure almost each country is encountering with (Mention, Ferreira, \& Torkkeli, 2020). In early days, the citizens with less information about the coronavirus resisted to change their lifestyle but with the passage of time they had to accept the reality (Harmon-Jones \& Harmon-Jones, 2007); and led to social distancing (Allcott et al., 2020; Matrajt \& Leung, 2020; WilderSmith \& Freedman, 2020). The world before coronavirus was quite different, but now one has to accept the reality and live a life with new realities surfaced on this planet (Harari, 2020). Different governments in various parts of the world are considering to introduce certain methods to judge human body. Having the confusing faith in viruses, the Coronavirus challenged the people's long standing social as well as cultural patterns of interconnection (Palitsky, Schmitt, Sullivan, \& Young, 2020). This virus not only changed human's psychological response to the pandemics, but also provided a challenging ray of hope for survival. Threats to human life (Efferth \& Paul, 2017; Fukuda-Parr, 2003) and unreliable information about the Coronavirus (Ashrafi-rizi \& Kazempour, 2020; Nielsen, Fletcher, Newman, Brennen, \& Howard, 2020) resulted into daunting anxieties which further affected humanity's basic impulses of psychological as well as social responses (Rosen, 2007) to pandemics while damaging economic and cultural milieu (Rhodes, 2002). Jean Paul Sartre termed it a 'bad faith' on the pretext of defensive reactions (Darnell, 2004). However, the US Senate as well as different representatives of the United States of America including the President-elect Joe Biden termed it an 'irresponsible statement, an ignorant and lethargic response' by President Donald Trump to fight against COVID-19, consequently, coronavirus strongly affected the US Presidential election (Hannah, Woolley, \& Luehrmann, 2020; Pielke Jr \& Lane, 2020). Factually, Joe Biden proved true in his statements pertaining to Donald Trump for cheating publics on the pretext of Covid-19 (Emerson \& Michaels, 2020).

So is the case in some other countries as well. Disasters striking in remote areas of the globe have immediate psychological impact on citizens and defensive response towards the occurrences (Pfefferbaum et al., 2014). However, it depends on the healthcare providers as well as community members that with which extent they respond to the disasters and pandemics. In Al-Jouf, a region in Saudi Arabia, where Coronavirus outbreak was higher than other regions but the people residing in the region gave minimal attention towards the pandemic. The government, however, responded timely by sending healthcare providers towards the affected areas who educated the uneducated persons and convinced them to adopt defensive steps (Nooh et al., 2020). Meanwhile, Bankers who is considered the decent and educated section of society shown comparative good knowledge about the consequence of the coronavirus (Bukht \& Javed, 2020). Several research studies have recommended that more awareness is required to educate the educated as well as uneducated class about the coronavirus (Guan, Zhou, Zhang, Peng, \& Chen, 2020). This is not the sole job of the public sector to educate masses but the citizens, healthcare providers and all other stakeholders need to take the collective responsibility of public guidance. Most of the people residing in affected areas require clinical support as well as technical knowledge like working of respiratory system and effects of the virus (Guan et al., 2020). Like other regions, the people of Pakistan with different demographic conditions have different awareness level of the novel coronavirus, but overall most of the respondents believed they had adequate knowledge about the virus but a small portion of population still needed the awareness (Javaid \& Javaid, 2020). Pakistani government as well as masses need to follow the response strategies of the government and awareness methods adopted by the people of China.

\section{Coronavirus: Behavior of Pakistanis during Pandemic Peak}

Critics believed the disasters and diseases like COVID-19 have always far long effects on social, political and economies one the life of the countries. However, there is a dire need to develop public perception or even build their minds towards such catastrophes so that they may take such happenings serious. Nooh et al. (2020) conducted a cross sectional study on 384 respondents in Al-Jouf area of 
Saudi Arabia to measure public perception and the best possible knowledge the respondents had towards the pandemic. The results showed that overall public had good knowledge about the lethal outcomes of the disease, however, they were unaware about the communicability and time period of the cure. Kharma, Alalwani, Amer, Tarakji, and Aws (2015) conducted a study from the perspective of the government to know the responsibility and concluded that healthcare providers were the primary persons who should educate public about the virus. Bdair, Alshloul, and Maribbay (2020) conducted a study with participation of 575 respondents aiming to know public perception, attitude and practices section of the public towards COVID-19. The findings showed that overall general public had adequate knowledge about the pandemic, however, there were negative tendencies and bad faiths (Bdair et al., 2020; Darnell, 2004) among the respondents towards the pandemic. Chen, Xu, Paris, Reeson, and Li (2020) believed the people with greater awareness level had greater migration ties towards epicenter in Wuhan as compared to those who were with less information about the pandemic. Accordingly, the people with greater awareness level had adopted preemptive measures to reduce the damage from the virus. Ikhlaq, Hunniya, Riaz, and Ijaz (2020) conducted a cross sectional study, choosing respondents from medical college in Lahore. The study showed that over 80 percent medical students have sufficient knowledge about the virus whereas there were a fewer MBBS students were required more details about the COVID-19. Ahmed et al. (2020) while conducting a cross sectional study found that although people [educated] have satisfactory knowledge and details about the novel coronavirus but implementation of the precautionary strategies were inadequate. The study showed that 72 percent practicing measures were noticed among 52 percent healthcare professionals in Pakistan. overall, 81.9 percent respondents shared the symptoms of COVID-19 were quite similar to flue. Interestingly, a huge portion of 73 percent respondents never bothered to attend any workshop, lecture etc., to acquire knowledge about the novel virus (Ahmed et al., 2020). Palalioglu et al. (2020) conducted a prospective study on 529 pregnant women in Turkey to know awareness and anxiety level towards the pandemic. The researchers distributed a validated questionnaire containing 51 questions. The results showed satisfactory correlation between anxiety and awareness but the patients with heart disease were more aware about the costs and precautionary measures. Qarawi et al. (2020) conducted a multinational survey study to examine the response capacity of the hospitals and other medical staffs. They concluded the Chinese government had greater medical equipment and response capacity to deal with this global pandemic but even then awareness among the citizens was the prime source of reducing the danger of the novel virus. Xiao et al. (2020) conducted a nation-wide cross sectional survey study comprising college students as respondents. The researchers came up with the conclusion that the government's measures of 'harsh social distancing' led to curtailing the pandemic spreading across the country. According to the results, the government's utilization of multiple channels for dissemination of information about the COVID-19 proved fruitful and fetched positive outcomes. However, the citizens as well as the governments of the third world countries different approach to fight against COVID-19 (Wu \& McGoogan, 2020).

Dwivedi et al. (2020) shared that in start of the Covid-19, almost every society of the third world countries did not take it serious and continued the social patterns of life in the footprints of the previous practices. However, Donthu and Gustafsson (2020) believed with the severe impact of this pandemic on human life, the citizens started taking it serious and adopted the ways of modern countries to curtail the danger of Covid-19. Even then there are some social, political and even religious factions of communities in different societies, who put the entire responsibility of tackling such issues on the shoulders of the government. The literature review showed that creating awareness is not the sole job of the government but every citizen needs to take social responsibility only then such situation can be controlled. The literature, however, found gap of knowledge in a sense that what was the comparison of awareness level and the cognitive dissonance between educated and uneducated class.

\section{Coronavirus and Cognitive Dissonance}

The people with ample knowledge about any dangerous situation logically leads them to adopt precautionary measures but even then, people behave negatively, meant they suffered from cognitive dissonance. For instance, some persons opine Negroes had all positive traits of Whites, but even then 
they would not like to see any Negro residing in their community (Brehm \& Cohen, 1962; Festinger, 1957); so, such sort of people remain consistent with their inward behavior. The person suffering from dissonance remains uncomfortable until he achieves consonance (Van Veen, Krug, Schooler, \& Carter, 2009) if he truly wants to change his behavior (Beasley \& Joslyn, 2001; Lieberman, Ochsner, Gilbert, \& Schacter, 2001). Generally, our decision-making capacity requires reduction in cognitive dissonance (Jarcho, Berkman, \& Lieberman, 2011); even after 50 years of its origin, this theory says the persons desiring consonant cognition need to change their dissonant behavior (Harmon-Jones \& Harmon-Jones, 2007). Sometime, people adopt bad faith during crisis situation as they admit the faults but cannot avoid themselves committing it (Palitsky et al., 2020). The researchers have applied the theory of cognitive dissonance to the research in hand hypothesizing that uneducated people accept the detrimental effects of the coronavirus but even then they would never change their behavior towards the pandemic (Mention et al., 2020; Yong, 2020). Accordingly based on the previous literature, the researchers have identified gap to explore answers to the following questions. Rese 3 arch questions of the study are:

RO1: To analyze the existing social patterns of public behavior in response to COVID-19

RO2: To analyze awareness, attitude and behavior of educated and uneducated people pertaining to COVID-19.

As previous studies echo that awareness of COVID 19 have positive association with media campaigns and change in attitudes and behavior is also noticed accordingly. But in case of Lahore, people behavior towards COVID 19 was considered negative as, the minister of health, Yasmeen Rashid also generated controversy by saying that Lahoris did not abide by the SOPs during pandemic peak as she was quoted as saying, "Sometimes I think Lahoris [feel they] are a special creation of God who are never ready to listen." She was complaining Lahoris for not maintaining social distancing (Geo, 2020).

So, after observing attitudes of Lahoris and the available literature on citizens' attitude during pandemic days, the following hypothesis are suggested within framework of cognitive dissonance theory.

H1: Educated Citizens will more likely to adopt preventive measures against Coronavirus as compared to Uneducated People.

H2: Uneducated Citizens will more likely to be in state of cognitive dissonance than educated people.

\section{Research Methods}

This study is quantitative in nature. A convenient sample size of 500 citizens was taken from Lahore with the 250 division of educated and uneducated people equally. A self-administered close ended questionnaire was developed aimed at analyzing awareness, attitude and behavior of the respondents. The survey was conducted online for 250 uneducated people, as convenient sampling, using Google Forms. Total 988 forms were sent to the respondents of Lahore until the researchers got a total number of 250 respondents during the time span of 25 days. Also, 250 uneducated people, who could not read or write were approached physically in teams and forms were get completed by getting response in their indigenous language. As there was a convenient sampling, therefore, the sample may have limitations to be representative of the total population of Lahore. Reason for choosing Lahore was that, it is the second largest populous City of Pakistan which had the maximum numbers of corona virus cases as compared to the other cities of Pakistan, at the time of the study, i.e. June 2020.

There were total 500 respondents out of which $27 \%$ of them were females. As the data was collected from two categorical variables, Educated and Uneducated. Educated people are considered those who have got education from any institution at minimum matriculation level to maximum PhD. Whole Uneducated people were considered those who could not read or write. After the data collection, there were $31 \%$ frequency of Post Graduate citizens, 3\% of them were graduate or Inter and $10 \%$ were doctorate. Rest of the 50\% were Uneducated. Around 33\% of the respondents were between the age of 25 to 35 years, $15 \%$ of them were between 35 to 45 years, $26 \%$ of them were between 55 to $65 \%$ and $18 \%$ of them were above 65 years. There were $5 \%$ young respondents whose age was between 15 to 25 years. 


\section{Data Analysis}

Descriptive Statistics of the participants with gender and education is as follows.

Gender

\begin{tabular}{|ll|l|l|l|l|}
\hline & Frequency & Percent & Valid Percent & $\begin{array}{l}\text { Cumulative } \\
\text { Percent }\end{array}$ \\
\hline \multirow{2}{*}{ Valid } & Male & 363 & 72.6 & 72.6 & 72.6 \\
& Female & 137 & 27.4 & 27.4 & 100.0 \\
& Total & 500 & 100.0 & 100.0 & \\
\hline
\end{tabular}

Education

\begin{tabular}{|c|c|c|c|c|c|}
\hline & & Frequency & Percent & Valid Percent & $\begin{array}{l}\text { Cumulative } \\
\text { Percent }\end{array}$ \\
\hline \multirow{6}{*}{ Valid } & Uneducated & 250 & 50.0 & 50.0 & 50.0 \\
\hline & INTER & 19 & 3.8 & 3.8 & 53.8 \\
\hline & Graduate & 19 & 3.8 & 3.8 & 57.6 \\
\hline & Post Grad & 159 & 31.8 & 31.8 & 89.4 \\
\hline & Doctorate & 53 & 10.6 & 10.6 & 100.0 \\
\hline & Total & 500 & 100.0 & 100.0 & \\
\hline
\end{tabular}

As a questionnaire was distributed among the educated and uneducated respondents to analyze awareness, attitude and behavior in response to the pandemic in order to check the effect of education on behavior change. The alpha coefficient for the scale was .830 (>0.70), suggesting high internal consistency. Content validity of the questionnaire was also assessed and revised by circulating it among 5 experts of Media and Communications discipline. In view of the experts the survey was modified to measure three constructs; including awareness, attitude and behaviour. The objective of the study was also to figure out whether education has an impact on getting people out of the state of cognitive dissonance. To check the state of cognitive dissonance after measuring the behaviors of the educated and uneducated people, the Independent T-Test was applied to analyses group differences.

The data showed that educated and uneducated people do not significantly differ in having awareness of COVID-19 (Alahdal, Basingab, \& Alotaibi, 2020) same as it happened in Egypt (Abdelhafiz et al., 2020). Their attitude towards COVID-19 between the groups is also not statistically significant too but the behavior is significantly different between the educated and uneducated groups, implying the uneducated people are in the state of cognitive dissonance than the educated people. It can also be implied that education as an independent variable leaves positive impact on people to bring them out of cognitive dissonance and respond to the pandemic in a responsible way.

Measuring the construct of awareness, data showed that TV and social media are the major source in giving awareness to the COVID-19. TV gave awareness to $60 \%$ of the respondents followed by social media, $23 \%$ and family and friend by $10 \%$ to uneducated citizens only. Both the educated and uneducated citizens were conscious about the exact awareness regarding COVID-19 on media campaigns without any significant difference $\mathrm{t}(498)=2.717, \mathrm{p}=0.07$.

Educated and Uneducated equally knew that there should be social distance of 6 feet, $\mathrm{t}(498)=0.000, p$ $=1.000$, about major COVID-19 symptoms the educated people are more aware of the symptoms than uneducated people $\mathrm{t}(498)=-9.2, p=0.000$. In response to the question regarding wearing mask, washing hands and keeping social distancing are the important ways to get save from the infection; agreement found in both educated and uneducated groups $t(498)=-.427, p=0.670$. This implies that both groups have not only awareness but an attitude of staying safe by following the standard operation 
procedure. But on the later action stage, i.e., behavior, the data results are statistically significant as both groups differ in behaviour implying the uneducated group keeps on violating COVID-19 SOPs knowing the impending danger of being infected, hence found in the state of cognitive dissonance.

Similarly Regression test was also applied and result indicates statistically significant difference $(\mathrm{p}=0.000)$ between educated and uneducated citizens on Lahore on keep on washing hands.

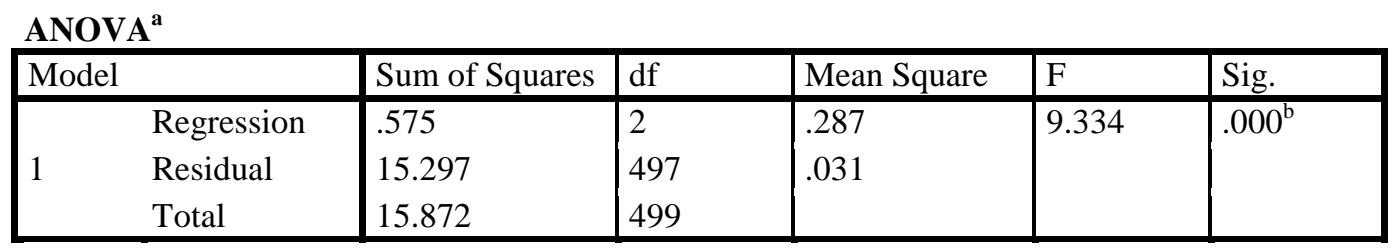

a. Dependent Variable: WashHands

b. Predictors: (Constant), NoEdu, Education

\begin{tabular}{|c|c|c|c|c|c|c|}
\hline \multicolumn{7}{|c|}{ Coefficients $^{\mathrm{a}}$} \\
\hline \multirow{2}{*}{\multicolumn{2}{|c|}{ Model }} & \multicolumn{2}{|c|}{ Unstandardized Coefficients } & \multirow{2}{*}{$\begin{array}{l}\begin{array}{l}\text { Standardized } \\
\text { Coefficients }\end{array} \\
\text { Beta } \\
\end{array}$} & \multirow[t]{2}{*}{$\mathrm{t}$} & \multirow[t]{2}{*}{ Sig. } \\
\hline & & B & Std. Error & & & \\
\hline \multirow{3}{*}{1} & (Constant) & $\overline{1.000}$ & .011 & & 90.124 & .000 \\
\hline & Education & .055 & .014 & .637 & 3.809 & .000 \\
\hline & NoEdu & -.187 & .060 & -.524 & -3.137 & .002 \\
\hline
\end{tabular}

a. Dependent Variable: WashHands

On analyzing the action of both groups towards following Corona SOPs, the educated group was found more cautious than the uneducated group. On question of how much they stayed at home during peak of the pandemic, educated groups; on five point Likert scale from Strongly Agree to Strongly Disagree (1 to 5: 1= Strongly Agree, 2= Agree, 3= Neutral, 4= Disagree, 5= Strongly Disagree), was found close to mean of Agree i.e., $M=1.7$, whereas the uneducated class found away from it and close to Disagreement $M=3.9$. This implies that uneducated class did not stay at home during peak of the pandemic days. This difference in behavior of both groups was found statistically significant $t(498)=21.52, p=0.000$. On a question of how frequently do they wear mask while going outside, mean of educated and uneducated groups was found significantly different $\mathrm{M}=1.6$ and $\mathrm{M}=4.2$ respectively, with $\mathrm{t}(498)=-.3521, \mathrm{p}=$ 0.000 .

Overall result of $\mathrm{T}$ test to see significant difference $(p=0.000)$ between behaviors towards COVID 19 is seen in the table below. The statistics indicate that educated people abide by the COVID SOPs more than that of uneducated citizens of Lahore.

\section{Paired Samples Test}

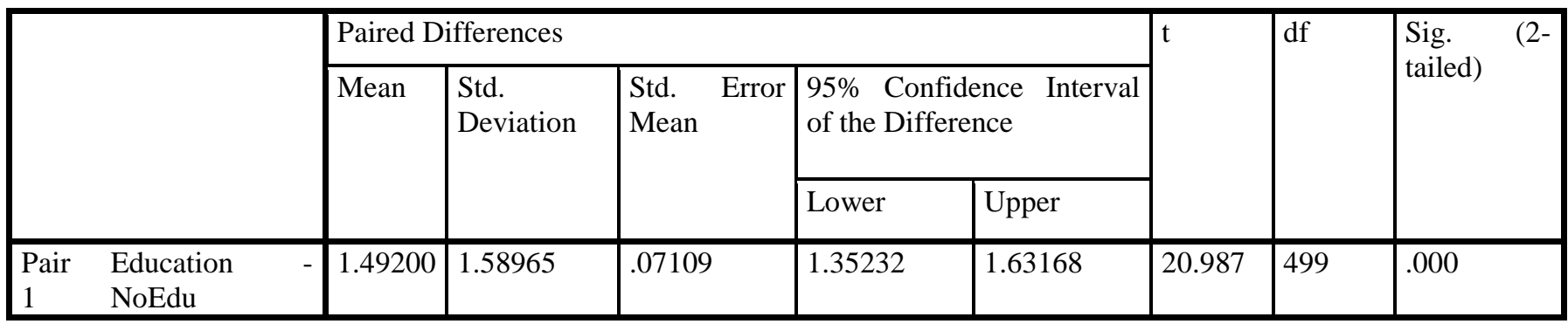

Uneducated group (M=3.8) have been frequently attending social gathering, even than by knowing the 
consequences. While educated group avoided gatherings during pandemic peak $(M=1.7)$. The T test also showed statistically significant mean difference between the groups $t(498)=-35.210 p=0.000$. On the question of taking precautionary measures while going outside, educated group acted upon the SOPs $(\mathrm{M}=1.6)$ while the Uneducated did not bother $(\mathrm{M}=3.3), \mathrm{t}(498)=-24, \mathrm{p}=0.000$.

Response to the sick people is found to be helpful from being infected. Both of the groups were asked how they respond when they see a sick person sneezing or coughing. The ultimate behavior should be to keep distance from the sick. Significant difference in behavior of both groups was sees as educated groups maintain immediate distance when the meet or see a sick people $(M=1.1)$ while the uneducated people did not $(\mathrm{M}=2.7) ; \mathrm{t}(498)=-19.06, \mathrm{p}=0.000$.

Use of sanitizers is considered useful precaution against COVID-19. On analyzing behavior of the two groups whether they use sanitizers, the educated group frequently used while the uneducated group did not $(\mathrm{M}=3.7$ and 1.7 respectively). The difference in their behavior was also statistically significant $\mathrm{t}$ $(399)=-33.60, \mathrm{p}=0.000$.

On a question of maintaining societal distance of six feet as per the suggested SOP, regardless of the awareness by both groups, educated group acted upon the SOP while the other did not (M=4.4 and 1.3 respectively); $\mathrm{t}(473)=-60.047, \mathrm{p}=0.000$. This implies that the uneducated group know the SOP, believes the spread of virus too but in state of cognitive dissonance by not changing its behavior of maintaining social difference.

Meeting people by shaking hands and hug is being discouraged. Same behaviour was measured from the sample and data shows that educated group is more likely to meet people from distance while the uneducated group did not ( $\mathrm{M}=4.0$ and 1.9 respectively). The findings of Independent $\mathrm{T}$-test also showing statistically significant mean between the groups $\mathrm{t}(404)=-25.68, \mathrm{p}=0.000$.

\section{Conclusion and Discussion}

After analyzing the data, it is found that educated Citizens are more likely to adopt preventive measures against Coronavirus as compared to Uneducated People supporting Hypothesis H1. Whereas, it is also found that regardless of the awareness of COVID-19 spread and infection, the uneducated class is less likely to adopt preventive measures against the virus, their behaviour is not changed in context of the pandemic. This also implies that the educated class is in state of cognitive dissonance. Hence the Hypothesis H2, "Uneducated Citizens will more likely to be in state of cognitive dissonance than educated citizens" is also supported. It is found that mass media is creating massive awareness and respondents, regardless of the education, are aware of the pandemic and its precautions. The awareness of the virus spread and pre cautions to prevent are perceived correctly as the result of broadcast and digital media campaigns. The attitude towards following SOPs is also somewhat positive. Educated group to a large extent and uneducated group to a considerable extent think that the SOPs should be followed. But on the stage of action, the uneducated class deviate from the awareness and attitude they have regarding corona and falls victim to the state of cognitive dissonance. Why? there is nothing wrong with the media campaigns, the communication process for awareness is correctly transmitted, citizens know and believe but do not act. The findings of the study indicated that education is the independent variable that is leaving a positive impact on the respondents to get out of the state of cognitive dissonance. As the results indicate that majority of educated people are not in the state of cognitive dissonance. They act what they believe, while the uneducated people do not act what they believe in context of the pandemic. Besides the education there can be other more reasons for the uneducated group not acting what they believe. As the survey was conducted from the uneducated people who could hardly read and write and they are those people whose social economic status is not that good. They may not afford sanitizers or masks and even may not avoid social gathering owing to the struggle to earn bread and butter. Citizens working in crowded vegetable market of Lahore (sabzi mandi), laborers at shops, restaurants, construction and cart men may lack access to media for daily developments of COVID-19, they may lake in resources to cope with the virus too. There may be a reason that, the less 
you know the less the fear you will have, leading them to be in state of cognitive dissonance.

\section{Recommendations for Future Researchers}

Keeping in view the findings, further studies of behavior change in the uneducated group may be conducted based on their own experience of seeing and believing. If the members of the uneducated group saw their close relatives or friends being infected with corona virus, whether he/she stills stays in the state of cognitive dissonance? Media campaigns can also be designed in such a way that may appeal to uneducated class by accommodating "their" approach in order to follow the SOPs and to get out from the state of cognitive dissonance. In this study, education and awareness have been found out to be an important factor to make the citizens change their behavior as per the changing pandemic circumstances and stay out of the cognitive dissonance. The study also concluded that education is a key factor to take people out from cognitive dissonance. The relationship of education and cognitive dissonance can also be studied in further research to explore the theory for new dimensions.

\section{References}

Abdelhafiz, A. S., Mohammed, Z., Ibrahim, M. E., Ziady, H. H., Alorabi, M., Ayyad, M., \& Sultan, E. A. (2020). Knowledge, perceptions, and attitude of egyptians towards the novel coronavirus disease (COVID-19). Journal of Community Health, 1-10.

Ahmed, N., Shakoor, M., Vohra, F., Abduljabbar, T., Mariam, Q., \& Rehman, M. A. (2020). Knowledge, Awareness and Practice of Health care Professionals amid SARS-CoV-2, Corona Virus Disease Outbreak. Pakistan Journal of Medical Sciences, 36(COVID19-S4).

Alahdal, H., Basingab, F., \& Alotaibi, R. (2020). An analytical study on the awareness, attitude and practice during the COVID-19 pandemic in Riyadh, Saudi Arabia. Journal of infection and public health, 13(10), 1446-1452.

Allcott, H., Boxell, L., Conway, J., Gentzkow, M., Thaler, M., \& Yang, D. Y. (2020). Polarization and public health: Partisan differences in social distancing during the Coronavirus pandemic. NBER Working Paper(w26946).

Ashrafi-rizi, H., \& Kazempour, Z. (2020). Information typology in coronavirus (COVID-19) crisis; a commentary. Archives of Academic Emergency Medicine, 8(1).

Bdair, I. A., Alshloul, M. N., \& Maribbay, G. L. (2020). Public Awareness Toward Coronavirus Disease-2019. Asia Pacific Journal of Public Health, 1010539520949421.

Beasley, R. K., \& Joslyn, M. R. (2001). Cognitive dissonance and post-decision attitude change in six presidential elections. Political psychology, 22(3), 521-540.

Brehm, J. W., \& Cohen, A. R. (1962). Explorations in cognitive dissonance.

Bukht, N., \& Javed, M. K. (2020). Banker's Awareness of Corona Virus. International Journal of Medical Science in Clinical Research and Review, 3(03), : 251-255.

Chen, H., Xu, W., Paris, C., Reeson, A., \& Li, X. (2020). Social distance and SARS memory: impact on the public awareness of 2019 novel coronavirus (COVID-19) outbreak. medRxiv.

Covid, C., COVID, C., COVID, C., Bialek, S., Gierke, R., Hughes, M., . . . Skoff, T. (2020). Coronavirus Disease 2019 in Children-United States, February 12-April 2, 2020. Morbidity and Mortality Weekly Report, 69(14), 422.

Darnell, M. (2004). Being-looked-at: Ontological Grounding for an Ethics in Being and Nothingness. Sartre Studies International, 10(1), 15-24.

Donthu, N., \& Gustafsson, A. (2020). Effects of COVID-19 on business and research. Journal of business research, 117, 284.

Dwivedi, Y. K., Hughes, D. L., Coombs, C., Constantiou, I., Duan, Y., Edwards, J. S., . . Prashant, P. (2020). Impact of COVID-19 pandemic on information management research and practice: Transforming education, work and life. International Journal of Information Management, 55, 102211.

Efferth, T., \& Paul, N. W. (2017). Threats to human health by great ocean garbage patches. The Lancet Planetary Health, 1(8), e301-e303. 
Emerson, B., \& Michaels, J. D. (2020). Abandoning Presidential Administration: A Civic Governance Agenda To Promote Democratic Equality and Guard Against Creeping Authoritarianism. UCLA Law Review, Forthcoming.

Festinger, L. (1957). A theory of cognitive dissonance (Vol. 2): Stanford university press.

Fukuda-Parr, S. (2003). New threats to human security in the era of globalization. Journal of Human Development, 4(2), 167-179.

Guan, L., Zhou, L., Zhang, J., Peng, W., \& Chen, R. (2020). More awareness is needed for severe acute respiratory syndrome coronavirus 2019 transmission through exhaled air during non-invasive respiratory support: experience from China. European Respiratory Journal, 55(3).

Hannah, A. L., Woolley, C., \& Luehrmann, L. M. (2020). How will COVID 19 Impact the 2020 Election.

Harari, Y. N. (2020). The world after coronavirus. Financial Times, 20.

Harmon-Jones, E., \& Harmon-Jones, C. (2007). Cognitive dissonance theory after 50 years of development. Zeitschrift für Sozialpsychologie, 38(1), 7-16.

Ikhlaq, A., Hunniya, B.-E., Riaz, I. B., \& Ijaz, F. (2020). Awareness and Attitude of Undergraduate Medical Students towards 2019-novel Corona virus. Pakistan Journal of Medical Sciences, 36(COVID19-S4), S32.

Jarcho, J. M., Berkman, E. T., \& Lieberman, M. D. (2011). The neural basis of rationalization: cognitive dissonance reduction during decision-making. Social cognitive and affective neuroscience, 6(4), 460-467.

Javaid, S., \& Javaid, M. K. J. D. A. (2020). Survey on Corona Virus: A Case Study in Pakistan. International Journal of Medical Science in Clinical Research and Review, 3(02), 223-227.

Kharma, M. Y., Alalwani, M. S., Amer, M. F., Tarakji, B., \& Aws, G. (2015). Assessment of the awareness level of dental students toward Middle East Respiratory Syndrome-coronavirus. Journal of International Society of Preventive \& Community Dentistry, 5(3), 163.

Lieberman, M. D., Ochsner, K. N., Gilbert, D. T., \& Schacter, D. L. (2001). Do amnesics exhibit cognitive dissonance reduction? The role of explicit memory and attention in attitude change. Psychological science, 12(2), 135-140.

Matrajt, L., \& Leung, T. (2020). Evaluating the effectiveness of social distancing interventions to delay or flatten the epidemic curve of coronavirus disease. Emerging infectious diseases, 26(8), 1740.

Mention, A.-L., Ferreira, J. J. P., \& Torkkeli, M. (2020). Coronavirus: a catalyst for change and innovation. Journal of Innovation Management, 8(1).

Nielsen, R. K., Fletcher, R., Newman, N., Brennen, S. J., \& Howard, P. N. (2020). Navigating the 'infodemic': How people in six countries access and rate news and information about coronavirus: Reuters Institute.

Nooh, H. Z., Alshammary, R. H., Alenezy, J. M., Alrowaili, N. H., Alsharari, A. J., Alenzi, N. M., \& Sabaa, H. E. (2020). Public awareness of coronavirus in Al-Jouf region, Saudi Arabia. Journal of Public Health, 1-8.

Palalioglu, R. M., Karadeniz, O., Aytok, G. I., Palalioglu, B., Koyan, G. N., Erbıyık, H. I., \& Muhcu, M. (2020). Awareness of Coronavirus Disease from Conception to Delivery: Antenatal Mental Journey. Available at SSRN 3637320.

Palitsky, R., Schmitt, H., Sullivan, D., \& Young, I. F. (2020). An Existential Analysis of Responses to the 2020 Coronavirus Outbreak. Journal of Humanistic Psychology, 0022167820946900.

Perlman, S. (2020). Another decade, another coronavirus: Mass Medical Soc.

Pfefferbaum, B., Newman, E., Nelson, S. D., Nitiéma, P., Pfefferbaum, R. L., \& Rahman, A. (2014). Disaster media coverage and psychological outcomes: descriptive findings in the extant research. Current psychiatry reports, 16(9), 464.

Pielke Jr, R., \& Lane, N. (2020). Memo for President Biden: Five steps to getting more from science: Nature Publishing Group.

Qarawi, A. T. A., Ng, S. J., Gad, A., Mai, L. N., AL-Ahdal, T. M. A., Sharma, A., . . Hashan, M. R. (2020). Awareness and Preparedness of Hospital Staff against Novel Coronavirus (COVID2019): A Global Survey-Study Protocol. 
Rhodes, T. (2002). The 'risk environment': a framework for understanding and reducing drug-related harm. International journal of drug policy, 13(2), 85-94.

Rose, J. (2020). The Mortal Coil of Covid-19, Fake News, and Negative Epistemic Postdigital Inculcation. Postdigital Science and Education, 2(3), 812-829.

Rosen, A. M. (2007). Civilizing climate: social responses to climate change in the ancient Near East: Rowman Altamira.

Seah, I., Su, X., \& Lingam, G. (2020). Revisiting the dangers of the coronavirus in the ophthalmology practice: Nature Publishing Group.

Van Veen, V., Krug, M. K., Schooler, J. W., \& Carter, C. S. (2009). Neural activity predicts attitude change in cognitive dissonance. Nature neuroscience, 12(11), 1469-1474.

Wilder-Smith, A., \& Freedman, D. O. (2020). Isolation, quarantine, social distancing and community containment: pivotal role for old-style public health measures in the novel coronavirus (2019nCoV) outbreak. Journal of travel medicine, 27(2), taaa020.

Wu, Z., \& McGoogan, J. M. (2020). Characteristics of and important lessons from the coronavirus disease 2019 (COVID-19) outbreak in China: summary of a report of 72314 cases from the Chinese Center for Disease Control and Prevention. jama, 323(13), 1239-1242.

Xiao, H., Shu, W., Li, M., Li, Z., Tao, F., Wu, X., . . Hu, Y. (2020). Social Distancing among Medical Students during the 2019 Coronavirus Disease Pandemic in China: Disease Awareness, Anxiety Disorder, Depression, and Behavioral Activities. International Journal of Environmental Research and Public Health, 17(14), 5047.

Yong, E. (2020). Why the coronavirus is so confusing. The Atlantic Daily, 29, 2020. 